camp sites in the Belcher Islands in Hudson Bay and recently received by the National Museum of Canada.

Unfortunately little or no information is available about the circumstances of the finds so it is only possible to apply typological and technological methods of study. Here naturally the earlier work of Mathiassen has proved invaluable. It would seem that some of the objects must predate the historical period while others were clearly made after the introduction of iron to the district and cannot therefore belong to a period earlier than the middle of the sixteenth century and may well be a hundred years younger still. Influences from various outside areas are traced and comparisons made. The Eskimo culture has always had a special interest for prehistorians, for the conditions, and therefore the mode of life, of these arctic folk resemble to a considerable extent those obtaining in Magdalenian times. Comparisons, of course, cannot be pressed too far, but it is at least always helpful to have scientific descriptions and good illustrations of Eskimo implements.

\section{Youth Welfare in Australia}

REFERRING to the leading article entitled "Welfare of Youth" in NATURE of November 16, 1940, p. 627, Sir James Barrett, sometime chancellor of the University of Melbourne, and a well-known Australian occulist and surgeon, writes to say that in Australia the National Fitness Movement is getting well under way and relies on two organizations in the main for its efficiency, namely, the American Playground System and the municipalities, the latter item meaning decentralization. The American Playground System is now of vast proportion and aims not simply at physical efficiency but also at moral and mental development, since in competitive games rules are made and must be observed. In short, the aim is self-government.

But no playground in the United States or Australia, he writes, is of much service without trained playleaders who help to organize the activities and to enlist committees of parents who are taught what the movement means and how malnutrition can be avoided. In other words, the movement is a department in effect of the educational system. Dr. Gulick is the soul of the American movement, and those interested should read his work "The Philo. sophy of Play". The desire for play is innate in the animal kingdom, and is seen even in kangaroos. In human beings it is the mainspring which compels action, and it was the recognition of this fact that brought the modern playground into existence which, whilst originating in England, has been enormously developed and systematized in the North American continent.

\section{Folk-Lore of Pulmonary Tuberculosis}

IN a recent paper on this subject (Tubercle, 22, 55 ; 1941), Dr. J. D. Rolleston states that while engaged in the composition of previous papers on the medical aspects of folk-lore (see NATURE, 143, 111, 756 ; 1939) he had been struck by the numerous popular, as distinct from scientific, views concerning pulmonary tuberculosis. He had therefore collected the folklore of this disease, most of which was concerned with its prophylaxis and comparatively little with its ætiology and symptoms. As regards the ætiology it is noteworthy that long before it was held by the medical profession to be an infectious disease, pulmonary tuberculosis was regarded as such in some country districts in England as well as among the Karanja Indians and in Brazil. Among the causes of the disease in popular estimation were catching cold, inspiration of a very cold north wind, the sudden cure of skin diseases, especially scabies, and sexual excess.

The last factor accounted for the treatment by administration of the testes of a fox or chicken in folk medicine long before the introduction of endocrinology by Brown-Séquard. Dr. Rolleston classified the various folk-lore beliefs and methods in the prophylaxis and treatment of pulmonary tuberculosis as follows: (1) Transfer of the disease to other persons, animals and inanimate objects ; (2) animal, plant and mineral remedies apart from any idea of transfer ; (3) religious factors such as invocations to the Trinity, Virgin Mary and various saints, especially Pantaleon; (4) charms of different kinds, some of which dated from Anglo-Saxon times; (5) water in the form of drinking water or bathing in the sea, streams, wells and fountains; (6) one hundred and sixty-one miscellaneous remedies, such as the doctrine of signatures, the influence of the moon, odd numbers and mechanical methods.

\section{Sources of Information on Agriculture}

THE Association of Special Libraries and Information Bureaux is issuing a new series of revisions and expansions of sections of its Directory to be known as "A S L I B War-Time Guides to British Sources of Special Information". The first of this series "Fuel and Allied Interests" (excluding electricity) was issued last June. The second, entitled "Agriculture and Allied Interests", is now available A S L I B, 31 Museum Street, London, W.C.1. 5s. to members of A S L I B, 6s. to non-members). The Guide consists of forty mimeographed foolscap sheets and is divided into four sections. Section 1 summarizes the position of agriculture and describes the organization for agricultural education and research in time of war. Section 2 gives a list of sources of specialized information, indicating the nature of the work carried out and the publications issued by each body. Government and public departments, research organizations, agricultural colleges and university departments come into this category, together with professional and trade organizations and stock breeding societies. The third section provides a comprehensive list of periodicals and year books, those which print abstracts or lists of references being specified. The Guide concludes with a section consisting of subject indexes relating to both section 2 (sources of information) and section 3 (periodical publications). Compilation has been carried out in close collaboration with specialist advisers, and the details concerning the individual organizations have been supplied by the latter themselves. 